\title{
HUBUNGAN KUALITAS TIDUR DENGAN TEKANAN DARAH PADA LANSIA DI POSYANDU LANSIA RW II PUSKESMAS KEDUNGKANDANG KOTA MALANG
}

\author{
Ahmad Assiddiqy \\ Program Studi Profesi Ners STIKes Maharani Malang \\ Email :odicky9@gmail.com
}

\begin{abstract}
Poor sleep quality can change the stress hormone cortisol and the sympathetic nervous system so that it can increase blood pressure in the elderly. The purpose of this study was to determine the relationship of sleep quality with blood pressure in the elderly at PosyanduLansia RW II Kedungkandang Health Center, Malang. The study design used a correlational design with a cross sectional approach. The population of the study was 158 people, the determination using purposive sampling so that the research sample was 32 respondents. To determine the correlation of data collection techniques using a questionnaire. Data analysis method used is the spearmen rank test obtained $p$ value $=0.001,<0.050$ so that $\mathrm{Ho}$ is rejected, meaning that there is a relationship between sleep quality and blood pressure in the elderly in the Posyandu Elderly RW II Kedungkandang Health Center Malang. Poor sleep quality can change the stress hormone cortisol and the sympathetic nervous system, resulting in an increase in blood pressure. The results of the analysis found that most 18 (56.2\%) respondents experienced poor sleep quality in the elderly and most 19 (59.4\%) respondents had hypertension blood pressure between $140 / 90 \mathrm{mmHg}$ to $<160 / 90 \mathrm{mmHg}$ in the elderly. From this study it is expected that the elderly need to get enough sleep for $\square 6$ hours to reduce blood pressure. The next researcher is expected to be able to relate the factors that affect sleep quality with blood pressure and the importance of the elderly's participation in Posyandu.
\end{abstract}

Keywords: sleep quality, elderly, blood pressure

Abstrak : Kualitas tidur yang buruk dapat mengubah hormone stress kortisol dan system saraf simpatik sehingga bias meningkatkan tekanan darah pada lansia. Tujuan penelitian untuk mengetahui hubungan kualitas tidur dengan tekanan darah pada lansia di Posyandu Lansia RW II Puskesmas Kedungkandang Kota Malang. Desain penelitian mengunakan desain korelasional dengan pendekatan cross sectional. Populasi penelitian sebanyak 158 orang, penentuan menggunakan purposive sampling sehingga sampel penelitian sebanyak 32 responden.Untuk mengetahui korelasi teknik pengumpulan data menggunakan kuesioner. Metode analisa data yang di gunakan yaitu uji spearmen rank didapatkan nilai $p=0,001<$ 0,050 sehingga Ho ditolak, artinya ada hubungan antara kualitas tidur dengan tekanan darah pada lansia di Posyandu Lansia RW II Puskesmas Kedung kandang Kota Malang. Kualitas tidur yang buruk dapat mengubah hormon stress kortisol dan system syaraf simpatik, sehingga terjadi peningkatan tekanan darah. Hasil analisis didapatkan sebagian besar 18 (56,2\%) responden mengalami kualitas tidur buruk pada lansia dan sebagian besar 19 (59,4\%) responden memiliki tekanan darah hipertensi antara140/90 $\mathrm{mmHg}$ sampai< 160/90 mmHg pada lansia. Dari penelitian ini diharapkan lansia perlu mencukupi tidur malam > 6 jam guna menurunkan tekanan darah. Untuk peneliti selanjutnya diharapkan dapat menghubungkan dengan faktor-faktor yang mempengaruhi kualitas tidur dengan tekanan darah serta pentingnya keikutsertaan lansia keposyandu.

Kata Kunci: Kualitas Tidur, Lansia, Tekanan Darah.

\section{PENDAHULUAN}

Pertumbuhan penduduk lansia di Indonesia tumbuh dengan cepat,bahkan tercepat di banding kelompok usia lainnya. Peningkatan usia, harapan hidup, dan penurunan angka fertilitas mengakibatkan populasi penduduk lanjut usia meningkat. Proses degeneratif yang tejadi pada lansia menyebabkan terjadinya penurunan kondisi kesehatannya. Keluhan yang paling sering di alami lansia di antaranya adalah gangguan tidur (insomnia) yang menyebabkan terjadi penurunan kualitas tidur penderitanya. Menurunnya kualitas tidur tersebut berdampak buruk terhadap kesehatan dan kualitas hidup lansia (Madjid, 2014).

Menurut Potter dan Perry (2012) tidur yang normal memiliki 2 fase yaitu pergerakan mata yang tidak cepat (tidur nonrapid eye movement, NREM) dan pergerakan mata yang cepat (tidur rapid eye movement, REM). Tidur NREM di bagi menjadi empat tahapan. Tahap satu dan dua merupakan karakteristik dari tidur 
dangkal dan seserorang lebih mudah bangun. Tahap tiga dan empat merupakan tidur dalam dan sulit untuk dibangunkan.

Menurut Calhoun \& Harding (2012), apabila tidur mengalami gangguan dan tidak terjadi penurunan tekanan darah saat tidur, maka akan meningkatkan resiko terjadinya hipertensi yang berujung kepada penyakit kardiovaskuler. Berdasarkan hasil penelitian Riska Haviza \& Sugianto (2014), ditemukan bahwa kualitas tidur dengan kategori buruk mayoritas memiliki tekanan darah hipertensi. Apabila pada kualitas tidur mengalami durasi tidur yang pendek atau kualitas tidur yang buruk dapat meningkatkan tekanan darah pada seseorang. Berdasarkan hasil penelitian Setiyorini (2014), ditemukan bahwa kualitas tidur yang buruk dapat berpengaruh terhadap peningkatan tekanan darah, apabila kualiatas tidur seseorang semakin buruk maka akan meningkatkan resiko terjadi peningkatan tekanan darah.

Tekanan darah pada usia lanjut (lansia) akan cenderung tinggi sehingga lansia lebih besar beresiko terkena hipertensi (tekanan darah tinggi). Penyakit hipertensi merupakan penyakit yang timbul akibat adanya intraksi dari barbagai factor resiko terhadap timbulnya hipertensi. Hilangnya elaslitas teringan dan arterosklerosis serta pelebaran pembuluh darah adalah factor penyebab hipertensi pada usia tua. Pada umumnya hipertensi pria terjadi diatas usia 31 tahun sedangkan pada wanita terjadi setelah berumur 45 tahun.Hipertensi atau tekanan darah tinggi merupakan masalah kesehatan yang cukup dominan di negara-negara maju. Di indonesia, ancaman hipertensi tidak boleh di abaikan. Hal ini dapat di buktikan dengan kian hari penderita hipertensi di Indonesia semakin meningkat. Namun sayangnya dari jumlah total penderita hipertensi tersebut, barusekitar 50 persen yang terdeteksi dan diantara penderita hanya setengah yang berobat secara teratur. Bagi golongan masyarakat hingga keatas hipertensi benarbenar telah menjadi momok yang menakutkan (Suiraoka, 2012).

Di dunia, hipertensi di perkirakan menyebabkan 7,5 juta kematian atau berkisar antara $12,8 \%$ dari semua kematian, berdasarkan data WHO pada tahun 2014 terdapat sekitar 600 juta penderita hipertensi di seluruh dunia. Prevalensi tertinggi terjadi di wilayah Afrika yaitu sebesar $30 \%$. Prevalensi terendah terdapat di wilayah Amerika sebesar 18\%. Berdasarkan survey di indonesia pada tahun 2013 hipertensi memiliki prevalensi yang tinggi, yaitu sebesar $25,8 \%$. Di samping itu pengontrolan hipertensi belum adekuat meskipun sudah banyak tersedia obat-obatan yang efektif (DepKes, 2013).

RISKESDAS pada tahun 2013 mencatat prevalensi hipertensi di Indonesia sebesar $25,8 \%$, pada kelompok usia $25-44$ tahun sebesar $29 \%$, pada kelompok usia 45-65 tahun sebesar $51 \%$ dan pada usia $>65$ tahun sebesar 65\%. Berdasarkan RISKESDAS prevalensi penderita hipertensi yang paling banyak terjadi pada lansia yang berumur lebih dari 45 tahun. Menurut DINKES Jawa Timur pada tahun 2017 prevalensi hipertensi mencapai 33,15\%.

Berdasarkan studi pendahuluan yang dilakukan di Posyandu Lansia RW II Puskesmas Kedungkandang Kota Malang peneliti mewawancarai 10 orang lansia usia diatas 50 tahun dengan jumlah keseluruhan 158 lansia, ditemukan bahwa 6 orang lansia mengeluh tidak bisa tidur nyenyak, sering terbangun pada malam hari setelah itu sulit tidur kembali, dan sulit untuk mengawali tidur pada malam hari, dan 4 orang lansia rata-rata lama tidur malam hari kurang dari 5 jam, lansia mengeluh mudah pusing serta jarang tidur pada siang hari.

Berdasarkan hasil observasi ditemukan bahwa empat orang lansia memiliki tekanan darah rata-rata 150/100 $\mathrm{mmHg}$, dua orang lansia memiliki tekanan darah 140/70 $\mathrm{mmHg}$, dua orang lansia memiliki tekanan darah 160/100 $\mathrm{mmHg}$ dan dua orang lansia memiliki tekanan darah $120 / 70 \mathrm{mmHg}$.

\section{METODE PENELITIAN}

Penelitian ini menggunakan desain
penelitian Korelasional dengan
menggunakan rancangan cross sectional.
Sampel dalam penelitian ini 32 responden
dari populasi yang termasuk dalam kriteria
inklusi. Kriteria inklusi dari penelitian ini
terdiri dari: yang tercatat dalam posyandu,
bersedia menjadi responden, dapat
berkomunikasi dengan baik, jenis kelamin
(L/P), usia lanjut antara $60-74$ tahun, tidak


mengkonsumsi obat anti hipertensi. Dan tidak di pakai apabila termasuk kriteria eksklusi. Kriteria eksklusi dari penelitian ini terdiri dari: mempunyai riwayat tekanan darah tinggi, mempunyai riwayat penyakit kardiovaskuler, mempunyai riwayat penyakit gagal ginjal, mempunyai riwatat penyakit diabetes militus dan tidak menjalani terapi farmakologi (diuretik alfa-blocker, beta-

\section{HASIL PENELITIAN}

\section{Data Umum}

Tabel 5.1 Distribusi Frekuensi Berdasarkan Jenis Kelamin Responden di Posyandu Lansia RW II Puskesmas Kedungkandang Kota Malang

\begin{tabular}{ccc}
\hline Jenis Kelamin & F & $(\%)$ \\
\hline Laki-laki & 5 & 15,6 \\
Perempuan & 27 & 84,4 \\
Total & $\mathbf{3 2}$ & $\mathbf{1 0 0}$ \\
\hline
\end{tabular}

Berdasarkan Tabel 5.1 diketahui bahwa hampir seluruhnya $(84,4 \%)$ responden berjenis kelamin perempuan di PosyanduLansia RW II Puskesmas Kedungkandang Kota Malang.

Tabel 5.2 Distribusi Frekuensi Berdasarkan Umur Responden di Posyandu Lansia RW II Puskesmas Kedungkandang Kota Malang

\begin{tabular}{ccc}
\hline Umur & F & $(\%)$ \\
\hline Umur 60-64 Tahun & 14 & 44 \\
Umur 65-69 Tahun & 11 & 34 \\
Umur 70-74 Tahun & 7 & 22 \\
Total & $\mathbf{3 2}$ & $\mathbf{1 0 0}$ \\
\hline
\end{tabular}

Berdasarkan Tabel 5.2 diketahui bahwa kurang dari separuh (44,0\%) berumur antara 65-69 tahun di Posyandu Lansia RW II Puskesmas Kedungkandang Kota Malang.

Tabel 5.3 Distribusi Frekuensi Berdasarkan Pendidikan Responden di Posyandu Lansia RW II Puskesmas Kedungkandang Kota Malang

\begin{tabular}{ccc}
\hline Pendidikan & F & $(\%)$ \\
\hline SD & 19 & 60 \\
SMA & 11 & 34 \\
Perguruan Tinggi & 2 & 6 \\
Total & $\mathbf{3 2}$ & $\mathbf{1 0 0}$ \\
\hline
\end{tabular}


Berdasarkan Tabel 5.3 diketahui bahwa sebagian besar $(60,0 \%)$ responden berpendidikan SD di Posyandu Lansia RW II Puskesmas Kedungkandang Kota Malang.

Tabel 5.4 Distribusi Frekuensi Berdasarkan Pekerjaan Responden di Posyandu Lansia RW II Puskesmas Kedungkandang Kota Malang

\begin{tabular}{ccc}
\hline Pekerjaan & F & $(\%)$ \\
\hline IRT & 26 & 81,2 \\
Pensiunan & 2 & 6,2 \\
Swasta & 3 & 9,5 \\
Wiraswasta & 1 & 3.1 \\
Total & $\mathbf{3 2}$ & $\mathbf{1 0 0}$ \\
\hline
\end{tabular}

Berdasarkan Tabel 5.4 diketahui bahwa hampir seluruhnya $(81,2 \%)$ responden bekerja sebagai Ibu Rumah Tangga (IRT) di Posyandu Lansia RW II Puskesmas Kedungkandang Kota Malang.

Tabel 5.5 Distribusi Frekuensi Berdasarkan Kebiasaan Stres Responden di Posyandu Lansia RW II Puskesmas Kedungkandang Kota Malang

\begin{tabular}{ccc}
\hline Stres & F & $(\%)$ \\
\hline lya & 5 & 16 \\
Tidak & 27 & 84 \\
Total & $\mathbf{3 2}$ & $\mathbf{1 0 0}$ \\
\hline
\end{tabular}

Berdasarkan Tabel 5.5 diketahui bahwa hampir seluruhnya $(84,4 \%)$ responden tidak mengalami stress di Posyandu Lansia RW II Puskesmas Kedungkandang Kota Malang

Tabel 5.6 Distribusi Frekuensi Berdasarkan Konsumsi Obat anti hipertensi Responden di Posyandu Lansia RW II Puskesmas Kedungkandang Kota Malang

\begin{tabular}{ccc}
\hline Konsumsi Obat & F & (\%) \\
\hline lya & 20 & 62,5 \\
Tidak & 12 & 37,5 \\
Total & $\mathbf{3 2}$ & $\mathbf{1 0 0}$ \\
\hline
\end{tabular}

Berdasarkan Tabel 5.6 diketahui bahwa sebagian besar (62,5\%) responden tidak mengkonsumsi obat anti hipertensi di Posyandu Puskesmas Lansia RW II Kedungkandang Kota Malang.

Tabel 5.7 Distribusi Frekuensi Berdasarkan Kebiasaan Olahraga Responden di Posyandu Lansia RW II Puskesmas Kedungkandang Kota Malang

\begin{tabular}{ccc}
\hline Kebiasaan Olahraga & $\mathrm{F}$ & $(\%)$ \\
\hline lya & 31 & 96,9 \\
Tidak & 1 & 3,1 \\
Total & $\mathbf{3 2}$ & $\mathbf{1 0 0}$ \\
\hline
\end{tabular}


Berdasarkan Tabel 5.7 diketahui bahwa hampir seluruhnya (96,9\%) responden memiliki kebiasaan suka berolahraga seperti lari pagi atau mengikuti senam lansia minimal 1-3 kali seminggu di Posyandu Lansia RW II Puskesmas Kedungkandang Kota Malang.

\section{Data Khusus}

Tabel 5.1 Distribusi Frekuensi KualitasTidur Pada Lansia di Posyandu Lansia RW II Puskesmas Kedungkandang Kota Malang

\begin{tabular}{ccc}
\hline Kualitas Tidur & F & (\%) \\
\hline Baik $($ Skor $\leq 5)$ & 14 & 43,8 \\
Buruk $($ Skor $>5)$ & 18 & 56,2 \\
Total & 32 & 100 \\
\hline
\end{tabular}

Berdasarkan Tabel 5.1 diketahui bahwa sebagian besar $(56,2 \%)$ responden mengalami kualitas tidur buruk pada lansia di Posyandu Lansia RW II Puskesmas Kedungkandang Kota Malang dan kurang dari separuh $(43,8 \%)$ responden mengalami kualitas tidur baik.

Tabel 5.2 Distribusi Frekuensi Tekanan Darah Pada Lansia di PosyanduLansia RW II Puskesmas Kedungkandang Kota Malang

\begin{tabular}{lcc}
\hline \multicolumn{1}{c}{ Tekanan Darah } & F & (\%) \\
\hline Normotensi & 13 & 40,6 \\
Hipertensi $\mathrm{mmHg}-<140 / 90 \mathrm{mmHg})$ & 19 & 59,4 \\
$(>140 / 90 \mathrm{mmHg}-<160 / 90 \mathrm{mmHg})$ & $\mathbf{3 2}$ & $\mathbf{1 0 0}$ \\
\multicolumn{1}{c}{ Total } & 13 & \\
\hline
\end{tabular}

Berdasarkan Tabel 5.2 diketahui bahwa sebagian besar $19(59,4 \%)$ responden memiliki tekanan darah hipertensi antara 140/90 mmHg sampai < 160/90 mmHg pada lansia di Posyandu Lansia RW II Puskesmas Kedungkandang Kota Malang.

Tabel 5.3 Analisis Hubungan Antara Kualitas Tidur Dengan Tekanan Darah Pada Lansia di Posyandu Lansia RW II Puskesmas Kedungkandang Kota Malang

\begin{tabular}{|c|c|c|c|c|c|c|c|c|c|}
\hline \multirow{3}{*}{\multicolumn{2}{|c|}{$\begin{array}{l}\text { Hubungan antar } \\
\text { variabel }\end{array}$}} & \multicolumn{4}{|c|}{ Tekanan Darah } & \multirow{2}{*}{\multicolumn{2}{|c|}{ Total }} & \multirow{3}{*}{$p$} & \multirow{3}{*}{$R$} \\
\hline & & \multicolumn{2}{|c|}{ Normotensi } & \multicolumn{2}{|c|}{ Hipertensi } & & & & \\
\hline & & $f$ & $(\%)$ & $f$ & $(\%)$ & $\mathrm{F}$ & (\%) & & \\
\hline \multirow{2}{*}{$\begin{array}{l}\text { Kualitas } \\
\text { Tidur }\end{array}$} & Baik & 10 & 31,2 & 4 & 12,5 & 14 & 43,8 & \multirow{3}{*}{0,001} & \multirow{3}{*}{0,553} \\
\hline & Buruk & 3 & 9,4 & 15 & 46,9 & 18 & 56,2 & & \\
\hline \multicolumn{2}{|c|}{ Total } & 13 & 40,6 & 19 & 59,4 & 32 & 100 & & \\
\hline
\end{tabular}

Berdasarkan Tabel 5.3 membuktikan hasil analisis uji spearman rank didapatkan nilai $p$ $=(0,001)<(0,050)$ sehingga Ho ditolak, artinya ada hubungan antara kualitas tidur dengan tekanan darah pada lansia di Posyandu Lansia RW IIPuskesmas Kedungkandang Kota Malang, sedangkan nilai $r=0,553$ membuktikan bahwa terdapat hubungan positif yang sedang antara kualitas tidur dengan tekanan darah pada lansia, dimana kualitas tidur yang buruk mampu meningkatkan tekanan darah pada lansia menjadi hipertensi pada lansia. Hasil tabulasi silang 
didapatkan dari $18(56,2 \%)$ lansia yang mengalami kualitas tidur buruk menyebabkan sebanyak 15 (46,9\%) lansia mengalami hipertensi.

\section{PEMBAHASAN}

\section{KualitasTidur Pada Lansia}

Hasil penelitian menunjukkan bahwa sebagian besar lansia yang mengalami kualitas tidur buruk diketahui dari responden terbangun ditengah malam malam untuk ke kamar mandi, sering mengalami mimpi buruk, lama bisa tertidur sekitar 16-30 menit dan terbiasa bangun jam 4 pagi sehingga mengalami lama tidurmalam kurang dari 6 jam. Berdasarkan hasil penelitian juga didapatkan kurang dari separuh responden mengalami kualitas tidur baik dikarenakan melakukan tidur malam sekitar jam \pm 9 malam dengan mudah lelap, jarang terbangun ditengah malam, jarang mengalami mimpi buruk dan saat bangun pagi tubuh terasa segar. Berdasarkan hal tersebut maka lansia harus melakukan tidur minimal 6-7 jam pada malam hari untuk menjaga kesehatan agar terhindar dari peningkatan tekanan darah.

\section{Tekanan Darah Pada Lansia}

Hasil penelitian menunjukkan bahwa sebagian besar Responden yang mengalami hipertensi diketahui dari ratarata tekanan darah sistolik $139,37 \mathrm{mmHg} /$ diastolik $94,37 \mathrm{mmHg}$ sehingga perlu tindakan untuk menjaga tekanan darah tetap normotensi dengan mencukupi kualitas tidur. Peningkatan tekanan darah harus dicegah dan diobati dengan baik, untuk mengurangi angka komplikasi hipertensi. Perilaku pencegahan hipertensi yang dilakukan seperti mengontrol makanan dengan mengurangi konsumsi makanan asin atau berlemak, mengurangi stres, melakukan tidur malam tepat waktu sehingga tercukupi kebutuhan tidur selama 6 jam dalam satu hari, melakukan olahraga atau aktivitas fisik dan rutin mengontrol tekanan darah atau melakukan pemeriksaan kesehatan minimal 1 bulan sekali ke rumah sakit atau puskesmas.

\section{Hubungan Antara Kualitas Tidur Dengan Tekanan Darah Pada Lansia}

Hasil analisa data menggunakan uji spearman rank didapatkan nilai $p=(0,001)$
$<(0,050)$ sehingga Ho ditolak, artinya ada hubungan antara kualitas tidur dengan tekanan darah pada lansia di Posyandu Lansia RW II Puskesmas Kedungkandang Kota Malang, sedangkan nilai $r=0,533$ membuktikan bahwa terdapat hubungan positif yang sedang antara kualitas tidur dengan tekanan darah pada lansia, dimana kualitas tidur yang buruk mampu meningkatkan tekanan darah pada lansia menjadi hipertensi pada lansia. Hasil tabulasi silang didapatkan dari $18(56,2)$ lansia yang mengalami kualitas tidur buruk menyebabkan sebanyak 15 (46,9\%) lansia mengalami hipertensi.

Menurut Potter \& Perry (2012), seseorang yang mengalami kekurangan tidur dapat menyebabkan gangguan metabolisme dan endokrin yang berkontribusi menyebabkan gangguan kardiovaskular sehingga terjadinya hipertensi. Kualitas tidur yang buruk berdampak pada penurunan anti bodi dengan gejala lemas dan mudah lelah sehingga mengubah hormon stres kortisol dan sistem saraf simpatik, yang menyebabkan terjadi peningkatan tekanan darah. Penderita hipertensi membutuhkan kualitas tidur yang baik untuk meningkatkan kesehatan dan memulihkan kondisi tubuh agar tetap sehat.

Hasil penelitian ini sesuai dengan penjelasan Desti (2018), menjelaskan kualitas tidur yang buruk berdampak terhadap peningkatan tekanan darah sehingga mengalami hipertensi. Hal ini sesuai dengan pendapat Maas, dkk., (2011), menjelaskan apabila seseorang mengalami gangguan tidur, maka tekanan darah akan semakin meningkatkan sehingga beresiko terjadinya hipertensi karena tidur mengubah fungsi sistem saraf otonom dan peristiwa fisiologis lainnya yang mempengaruhi tekanan darah. Dampak peningkatan tekanan darah pada lansia yaitu muncul penyakit seperti stroke, serangan jantung, gagal jantung dan gagal ginjal.

\begin{tabular}{l}
\multicolumn{3}{c}{ Berdasarkan hasil penelitian dapat } \\
dipahami bahwa responden yang \\
mengalami kualitas tidur buruk bisa \\
menyebabkan peningkatan tekanan darah
\end{tabular}


menjadi hipertensi. Kualitas tidur yang buruk dapat mengubah hormon stres kortisol dan sistem saraf simpatik, sehingga terjadi peningkatan tekanan darah. Kualitas tidur yang buruk akan berpengaruh terhadap kenaikan tekanan darah sehingga bisa mengalami hipertensi sebagai pemicu timbulnya berbagai penyakit.

Peneliti menyadari dalam penelitian ini tentu menemukan keterbatasan penelitian, pada penelitian ini terdapat beberapa kekurangan seperti pengukuran tekanan darah waktu sesaat yaitu dimana pengukuran tekanan darah dilakukan hanya satu kali dan pengukuran tekanan darah jauh dari jam bangun tidur.

\section{KESIMPULAN DAN SARAN}

Sebagian besar $18 \quad(56,2 \%)$ responden mengalami kualitas tidur burukpada lansia di Posyandu Lansia RW II

\section{DAFTAR PUSTAKA}

Calhoun, D.a dan Harding, S.M. (2012). Sleep and Hypertension. Journal Circulation.

Desti Prastikasari., (2018). Hubungan Kualitas Tidur Dan Aktivitas Fisik Dengan Tekanan Darah Pada Lansia Di Posyandu Lansia Desa Setrorejo.

Dinkes Kota Malang (2017). Laporan Data Kesakitan Hipertensi. Malang.

Maas, M,. Dkk. (2011). Asuhan Keperawatan Geriatrik : Diagnosis Nanda, Kriteria Hasil NOC, \& Intervensi NIC. Jakarta : ECG.

Madjid, Yudi Abdul,. (2014). Pengaruh Akrupesur Terhadap Kualitas Tidur Lansia di Balai Perlindungan Soaial, Tresna Werdha Ciparay. http://digilip.unisayogya.ac.idDi Unduh tanggal 27 februari 2019, jam 20.00 WIB.

Puskesmas Kedung-Kandang (2012). Laporan Data Kejadian Hipertensi. Malang.
Puskesmas Kedungkandang Kota Malang. Sebagian besar 19 (59,4\%) responden memiliki tekanan darah hipertensi antara $140 / 90 \mathrm{mmHg}$ sampai < 160/90 $\mathrm{mmHg}$ pada lansia di Posyandu Lansia RW II Puskesmas Kedungkandang Kota Malang. Ada hubungan positif antara kualitas tidur dengan tekanan darah pada lansia di Posyandu Lansia RW II Puskesmas Kedungkandang Kota Malang, didapatkan nilai $p=(0,001)<(0,050)$ dimana kualitas tidur yang buruk mampu meningkatkan tekanan darah pada lansia menjadi hipertensi pada lansia.

Diharapkan penelitian ini mampu menjadi strategi dalam memberikan pelayanan kepada lansia melalui kegiatan posyandu serta bagi wacana untuk memberikan penyuluhan kepada lansia, khususnya dalam mendukung berlangsungnya kegiatan Posyandu Lansia.

Potter\& Perry,. (2012). Buku Ajar Fundamental Keperawatan : konsep, proses dan praktik keperawatan. Edisi4. Vol2. Jakarta : ECG.

Haviza,. (2014). Hubungan Kualitas Tidur Dengan Tekanan Darah Pada Usia Lanjut Di Posyandu Lansia Dusun Jelapan Sindu Martani Ngemplak Sleman Yogyakarta. http://digilip.unisayogya.ac.id Di Unduh tanggal 23 februari 2019, jam 22.00 WIB.

Suiraoka, IP. (2012) Penyakit Degeneratif. Yogyakarta : Nuha Medika.

Setiyorini Yekti,. (2014). Hubungan Kualitas Tidur Dengan Tekanan Darah Pada Lansia Hipertensi Di Gamping Sleman Yogyakarta. 